\title{
Camptodactyly, with muscular hypoplasia, skeletal dysplasia, and abnormal palmar creases: Tel Hashomer camptodactyly syndrome*
}

\author{
RICHARD M. GOODMAN, $\dagger$ MARIASSA BAT-MIRIAM KATZNELSON, \\ MARJORIE HERTZ, and ALEXANDER KATZNELSON
}

From the Departments of Human Genetics, Radiology and Orthopedic Surgery of The Chaim Sheba Medical Center, Tel Hashomer, Israel; and The Sackler School of Medicine, Tel Aviv University, Ramat Aviv, Israel

Summary. A syndrome characterized by camptodactyly, distinct facial features, multiple musculoskeletal defects, and unique dermatoglyphic changes is described in two sisters born of consanguineous parents. In 1972 this same constellation of findings was first reported in two sibs from a different ethnic origin. This heritable disorder of connective tissue termed the Tel Hashomer camptodactyly syndrome is thought to be transmitted as an autosomal recessive trait. The basic defect is unknown.

In 1972, we (Goodman, Bat-Miriam Katznelson, and Manor) described two new genetic disorders of connective tissue which presented with camptodactyly. Recently we had the opportunity of seeing for the second time one of these syndromes in two sibs from an Arab family. The purposes of this report will be to give a detailed account of the clinical features in this syndrome and to discuss its mode of inheritance.

\section{Family studies}

A 20-year-old unmarried Bedouin Arab woman with multiple malformations was referred to our diagnostic clinic for evaluation. On questioning the patient about her family, two important facts became known. She stated that she had an older sister with identical features and that her parents were first cousins.

The family pedigree is shown in Fig. 1. In addition to the two affected sibs and their mother, it was not possible to examine any of the other family members. The mother stated that her husband was in good health and did not have any physical defects. The mother did not know her true age but estimated that she was in her late forties. All of her children were born at home and she could not give a reliable history regarding all 13

Received 21 March 1975.

* This study was supported in part by a grant from the Lester Aronberg Foundation.

t Reprint requests to: Dr R. M. Goodman, Sheba Medical Center, Tel Hashomer, Israel. pregnancies. Five of her children died during the first year of life and the cause of death in each is not known. She denied that any of her other children were abnormal or in any way resembled her two affected daughters.

Physical examination of the proband showed that she had a strikingly similar constellation of findings that we first previously observed in two other sibs some three years ago. For purposes of evaluation and possible treatment both she and her sister, who was identically affected, were admitted to hospital. The positive physical findings in these two sibs are presented in

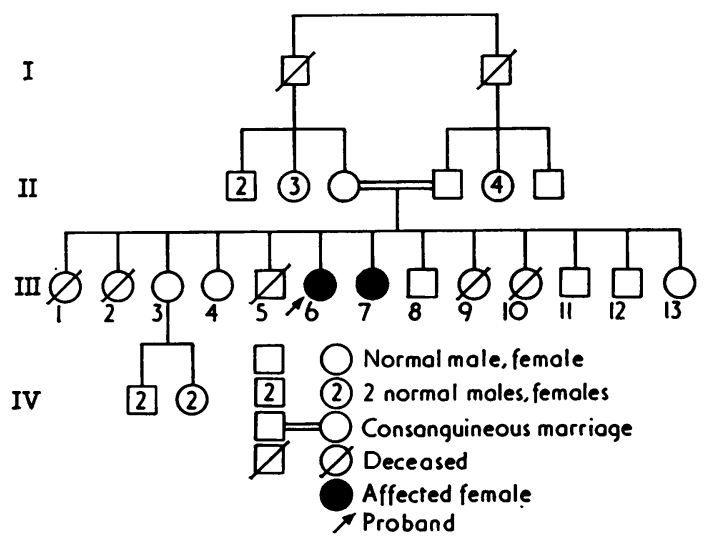

FIG. 1. The family pedigree. 
TABLE I

CLINICAL FINDINGS IN THE TEL HASHOMER CAMPTODACTYLY SYNDROME

\begin{tabular}{|c|c|c|c|c|}
\hline \multirow[b]{2}{*}{ Location and Defect } & \multicolumn{2}{|c|}{ Previous Cases } & \multicolumn{2}{|c|}{ New Cases } \\
\hline & $\begin{array}{c}\text { III.7 } \\
\text { aged } 17\end{array}$ & $\begin{array}{c}\text { III.3 } \\
\text { o aged } 13\end{array}$ & $\stackrel{\text { III.6 }}{\text { aged } 20}$ & $\begin{array}{c}\text { III.7 } \\
\text { ơ aged } 19\end{array}$ \\
\hline Stature & & & & \\
\hline Short & + & + & $+(152 \mathrm{~cm})$ & $+(150 \mathrm{~cm})$ \\
\hline $\begin{array}{l}\text { Skull } \\
\text { Brachycephaly }\end{array}$ & & & & \\
\hline Prominent forehead & $\begin{array}{l}t \\
t\end{array}$ & $\begin{array}{c}++ \\
+\end{array}$ & $\stackrel{+}{+}$ & $\begin{array}{l}+ \\
+\end{array}$ \\
\hline Facies & & & $T$ & + \\
\hline Asymmetry & ++ & + & \pm & + \\
\hline Ocular hypertelorism & + & + & + & + \\
\hline Small mouth & + & + & + & + \\
\hline $\begin{array}{l}\text { High arched palate } \\
\text { Increased philtrum length }\end{array}$ & $\begin{array}{l}+ \\
+\end{array}$ & $\begin{array}{l}+ \\
+\end{array}$ & $\begin{array}{l}+ \\
+\end{array}$ & $\begin{array}{l}t \\
t\end{array}$ \\
\hline $\begin{array}{l}\text { Increased philtrum length } \\
\text { Dental crowding }\end{array}$ & + & + & $\begin{array}{l}+ \\
+\end{array}$ & $\begin{array}{l}+ \\
+\end{array}$ \\
\hline Chest & & & & \\
\hline Thoracic scoliosis & + & ++ & + & + \\
\hline Winging of scapulae & + & ++ & + & + \\
\hline Extremities & & & & \\
\hline Camptodactyly & + & $+t$ & + & + \\
\hline $\begin{array}{l}\text { Syndactyly } \\
\text { Clinodactyly }\end{array}$ & $\stackrel{+}{-}$ & + & $\begin{array}{l}+ \\
+\end{array}$ & $\begin{array}{l}+ \\
+\end{array}$ \\
\hline Brachydactyly thumbs & - & - & + & + \\
\hline Spindle-shaped fingers & + & + & + & + \\
\hline Abnormal hand prints & + & + & + & + \\
\hline Dislocated radii & - & - & + & + \\
\hline Clubbed feet & + & + & - & - \\
\hline Pes planus & - & - & + & + \\
\hline $\begin{array}{l}\text { Malformed toes } \\
\text { Muscular system }\end{array}$ & + & + & + & + \\
\hline $\begin{array}{l}\text { Muscular system } \\
\text { Hypoplasia of chest }\end{array}$ & + & ++ & + & + \\
\hline Hypoplasia of pelvis & + & ++ & + & + \\
\hline Hypoplasia of limb and hand muscles & + & ++ & + & + \\
\hline
\end{tabular}

$-=$ absent, $\pm=$ mild,$+=$ present,$++=$ severe.

TABLE II

RADIOGRAPHIC FINDINGS IN TWO SIBS WITH THE TEL HASHOMER CAMPTODACTYLY SYNDROME

\begin{tabular}{|c|c|c|}
\hline Site & III. 6 ㅇ aged 20 & III.7 9 aged 19 \\
\hline Skull & $\begin{array}{l}\text { Brachycephalic; prominent maxilla on A-P; broad } \\
\text { mandible }\end{array}$ & Same as III.6 \\
\hline $\begin{array}{l}\text { Spine } \\
\text { Cervical }\end{array}$ & Spina bifida $C_{1}$; enlarged vertebral foramina $C_{3}$ & $\begin{array}{l}\text { Spina bifida } C_{1} \text {; enlarged vertebral foramina } C_{3} ; \\
\text { high vertebral bodies }\end{array}$ \\
\hline Thoracic & Mild rotational deformities of dorsal vertebrae & $\begin{array}{l}\text { Vertebral annular epiphyses present in all vertebrae; } \\
\text { mild scoliosis centred at th. } 9-10\end{array}$ \\
\hline Lumbar & Agenesis of left pedicle $\mathbf{L}_{4}$ with secondary scoliosis & Mild scoliosis of lumbar vertebrae to right \\
\hline Pelvis & Normal & Normal \\
\hline Thorax & Mild lateral retraction of chest wall & Same as III.6 \\
\hline $\begin{array}{l}\text { Upper extremities } \\
\text { Humerus }\end{array}$ & Hypoplasia of trochlea and capitellum & Same as III.6 \\
\hline Ulnar-radius & Posterior dislocation of radial head & Deformed and enlarged radial head \\
\hline Hands & $\begin{array}{l}\text { Clinodactyly; syndactyly skin only; brachydactyly } \\
\text { lst metacarpal right; narrow distal phalanges }\end{array}$ & Same as III.6 \\
\hline $\begin{array}{l}\text { Lower extremities } \\
\text { Femur }\end{array}$ & Normal & Normal \\
\hline Tibia, Fibula & Elongated fibula; subluxation of tibiotalar joint & Normal \\
\hline Feet & $\begin{array}{l}\text { Vertical talus right with deformity of left talus; } \\
\text { subluxation of subtalar joints; deformed na- } \\
\text { vicular; deformed and flattened calcaneous; } \\
\text { hallux valgus both big toes; subluxation of } \\
\text { interphalangeal joints of great toes, bilateral; } \\
\text { severe deformity of terminal digits of feet } \\
\text { bilateral }\end{array}$ & $\begin{array}{l}\text { Talus flat and deformed; subluxation of subtalar } \\
\text { joint; deformed navicular; deformed and flattened } \\
\text { calcaneous; brachydactyly of right metatarsals; } \\
\text { hallux valgus big toe right; subluxation of inter- } \\
\text { phalangeal joints of great toes, bilateral; severe } \\
\text { deformity of terminal digits of feet bilateral }\end{array}$ \\
\hline
\end{tabular}


TABLE III

DERMATOGLYPHIC FINDINGS IN THE TEL HASHOMER CAMPTODACTYLY SYNDROME

\begin{tabular}{|c|c|c|c|c|c|c|}
\hline Family Members & $\begin{array}{c}\text { No. } \\
\text { of } \\
\text { Whorls }\end{array}$ & $\begin{array}{l}\text { Total } \\
\text { Ridge } \\
\text { Count }\end{array}$ & $\begin{array}{l}\text { a-b } \\
\text { Ridge } \\
\text { Count }\end{array}$ & $\begin{array}{c}\text { Ridge } \\
\text { Breadth } \\
\text { (microns) }\end{array}$ & $\begin{array}{c}\text { Maximal } \\
\text { atd } \\
\text { angle }\end{array}$ & $\begin{array}{c}\text { Modification } \\
\text { of } \\
\text { Creases }\end{array}$ \\
\hline $\begin{array}{l}\text { Present family } \\
\text { III.6 affected } \\
\text { III.7 affected } \\
\text { Mother }\end{array}$ & $\begin{array}{l}9 \\
7 \\
4\end{array}$ & $\begin{array}{l}177 \\
209 \\
162\end{array}$ & $\begin{array}{l}77 \\
76 \\
62\end{array}$ & $\begin{array}{l}493 \\
697 \\
523\end{array}$ & $\begin{array}{l}75^{\circ} \\
92^{\circ} \\
68.5^{\circ}\end{array}$ & $\begin{array}{l}+ \\
+ \\
-\end{array}$ \\
\hline $\begin{array}{l}\text { Previous family } \\
\text { III.1 affected } \\
\text { III.3 affected } \\
\text { III.4 normal sib } \\
\text { III.6 normal sib } \\
\text { Father } \\
\text { Mother }\end{array}$ & $\begin{array}{l}8 \\
8 \\
3 \\
4 \\
3 \\
1\end{array}$ & $\begin{array}{l}271 \\
350 \\
135 \\
179 \\
163 \\
181\end{array}$ & $\begin{array}{r}73 \\
120 \\
75 \\
90 \\
79 \\
82\end{array}$ & $\begin{array}{l}606 \\
536 \\
428 \\
385 \\
561 \\
533\end{array}$ & $\begin{array}{c}110.5^{\circ} \\
101^{\circ} \\
76^{\circ} \\
90.5^{\circ} \\
71^{\circ} \\
82^{\circ}\end{array}$ & $\begin{array}{l}+ \\
+ \\
- \\
- \\
-\end{array}$ \\
\hline
\end{tabular}

Table I and they are compared with our two previous cases. Fig. 2 and 3 illustrate some of their characteristic physical features.

All routine laboratory studies in each patient were within normal limits including such investigations as serum and urine amino acids, serum aldolase, creatine kinase, transaminase (SGOT and SGPT), phosphorus, calcium, and electrolytes. Electromyographic studies along with electrocardiographic examination were also within a normal range. Serum gamma-globulin levels were slightly raised in each patient but serum protein immunoelectrophoretic studies did not show any significant alteration. Chromosome studies in the proband showed a normal female karyotype.

Muscle evaluation studies revealed that both patients had bilateral absence of the peronei muscles and extensor hallucis longus muscle of the lower extremities.

Multiple skeletal abnormalities were observed on

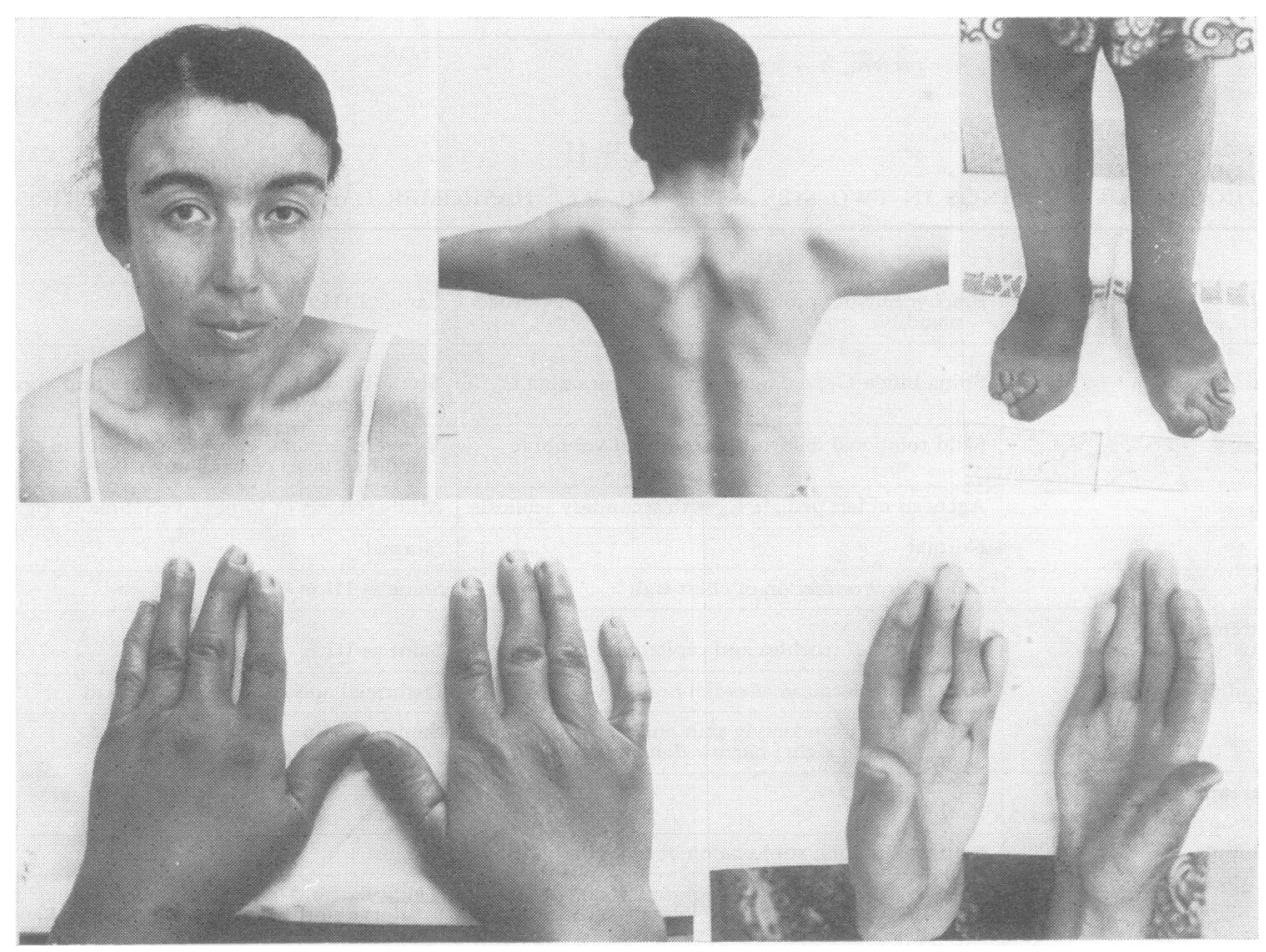

FIG. 2. The proband showing a prominent forehead, facial asymmetry, ocular hypertelorism, small mouth, increased philtrum length, poor muscle development involving the shoulders, lower extremities, and palmar muscles of the hand. One can also note the malformed toes, spindle-shaped fingers with camptodactyly. Syndactyly was also present but could only be detected when the fingers were spread. 
various $x$-ray studies, and these are presented in Table II and some are illustrated in Fig. 4.

Dermatoglyphic studies were done in the two affected sibs and their mother. A summary of these findings along with our previous observations are presented in Table III. Fig. 5 shows the very abnormal dermatoglyphic pattern in each affected sib.

The proband complained of pain and difficulty in walking. Her heels were in a valgus position, with short and overlapping toes. Both great toes were also in a valgus position and the left great toe was flexed so that the toe-nail came into contact with the ground (Fig. 2).

To ease her condition a corrective osteotomy was performed at the base of the proximal phalanx and the interphalangeal joint of the left great toe was arthrodesed.

\section{Discussion}

There is little doubt that these two sisters share almost the identical pattern of physical findings with our previous two cases of a sister and brother. Their common facial appearance and musculoskeletal deformities make this a distinct syndrome.
Of significant interest is the striking similarity in the dermatoglyphic configuration noted not only between the two affected sibs but also in the other two previous cases. Genetic disorders of chromosomal origin tend to have a higher degree of similarity (often diagnostic) in their dermatoglyphic patterns, in contrast, to autosomal or X-linked disorders. This heritable syndrome may well be one of the best exceptions to the above. The presence of digital whorls on seven or more digits which extend beyond the borders of the terminal phalanges, a low main line index caused by the very vertical orientation of the A-D radiants, coupled with numerous palmar creases obliterating the normal structure of the ridges and openings of the sweat pores, suggests a possible diagnosis through the use of dermatoglyphs, since, to the best of our knowledge, these findings are unique for this syndrome.

In our original report (Goodman et al, 1972), we postulated that this syndrome was transmitted as an

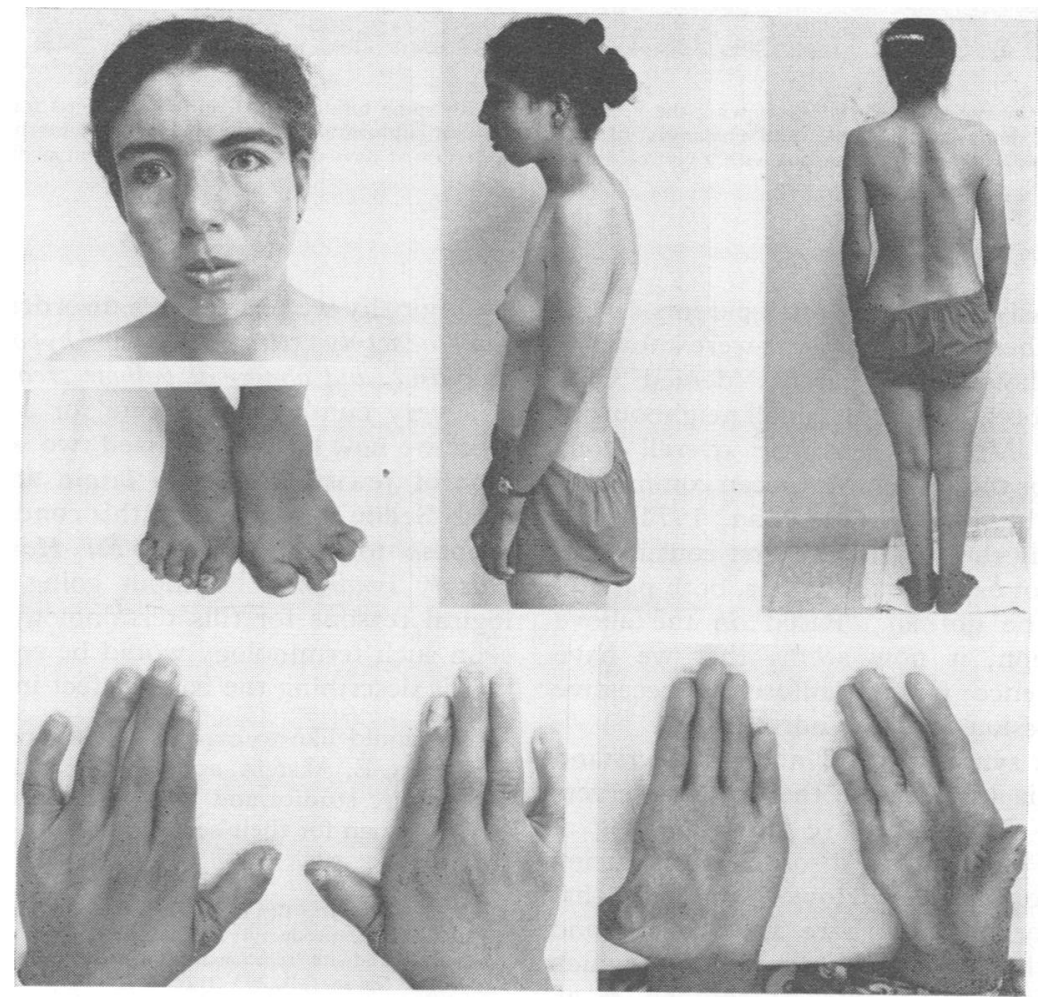

FIG. 3. The proband's 19-year-old sister showing a strong facial and body resemblance with a prominent forehead, facial asymmetry, ocular hypertelorism, small mouth, increased philtrum length, poor muscular development, as exhibited by a stooped posture, poor lower leg muscle development, and hypoplasia of the thenar and hypothenar eminences of the hands. Camptodactyly and spindle-shaped fingers can also be noted. 


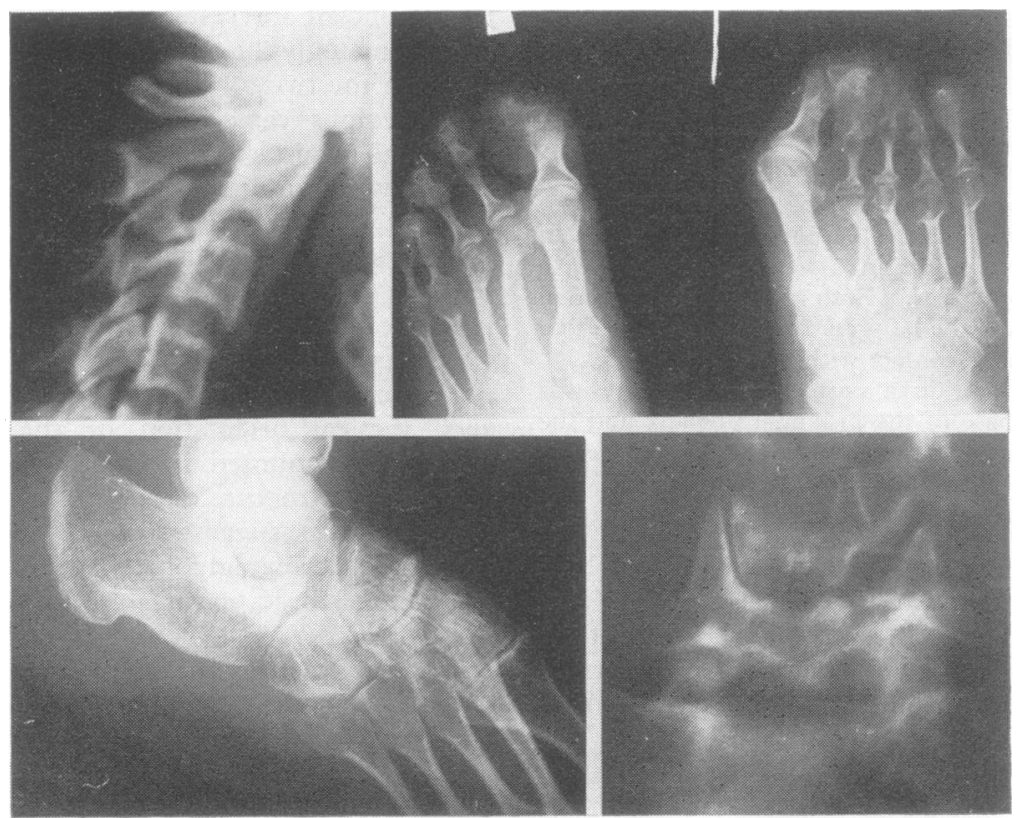

FIG. 4. $X$-rays from the two affected sisters showing the cervical spine with spina bifida of C-1 and an enlarged foramina of C-3; short metatarsals with thin shafts of metatarsals and phalanges, hallux valgus with subluxation of interphalangeal joints bilaterally, and overlapping of distal joints; a deformed calcaneous with a vertical talus and a deformed navicular; agenesis of the left pedicle of $L-4$ resulting in scoliosis.

autosomal recessive trait. Both parents were normal and no other family members were known to be affected. Though the parents denied consanguinity, they both came from small neighbouring communities in Morocco and the overall consanguinity rate for the Jewish Moroccan community is estimated to be $10.7<$ (Goodman, 1974). In the present family the parents are first cousins and though we did not examine the father, both parents are thought to be normal. Based on the above family information, it now seems that we have convincing evidence for an autosomal recessive mode of transmission in this syndrome.

To describe a syndrome and not to understand the basic defect is a frustration that most observers must live with. Essentially we know nothing of how the mutant gene in this disorder is producing the various malformations. However, it seems that this genetic disorder does share a common bond with all the other genetic syndromes in which camptodactyly is a key feature (Goodman et al, 1972). That common bond being that these disorders all involve various alterations in connective tissue.
Originally we termed this disorder, a syndrome of camptodactyly with muscular hypoplasia, skeletal dysplasia, and abnormal palmar creases. Since this is a very cumbersome name for a syndrome and since we now have recognized two separate families (one of Jewish Moroccan origin and the other of Arab Bedouin origin) with this condition, we would propose to call this the Tel Hashomer camptodactyly syndrome. Without going into the nosological reasons for this terminology, we hope that soon such terminology would be replaced by those words describing the basic defect in this disorder.

We would like to express our appreciation to $\mathrm{Dr} B$. Goldman, E. Akstein, and R. Chaki for performing the cytogenetic studies and to Mrs R. Langridge and Mrs R. Grossman for their secretarial help.

\section{REFBRENCES}

Goodman, R. M., Bat-Miriam Katznelson, M., and Manor, E. (1972). Camptodactyly: occurrence in two new genetic syndromes and its relationship to other syndromes. Fournal of Medical Genetics, 9, 203-212.

Goodman, R. M. (1974). Various genetic traits and diseases among the Jewish ethnic groups. In Medical Genetics Today. Birth Defects: Original Article Series 10, No. 10, pp. 205-219. Ed. by D. Bergsma. William and Wilkins, Baltimore for the National Foundation-March of Dimes, New York. 


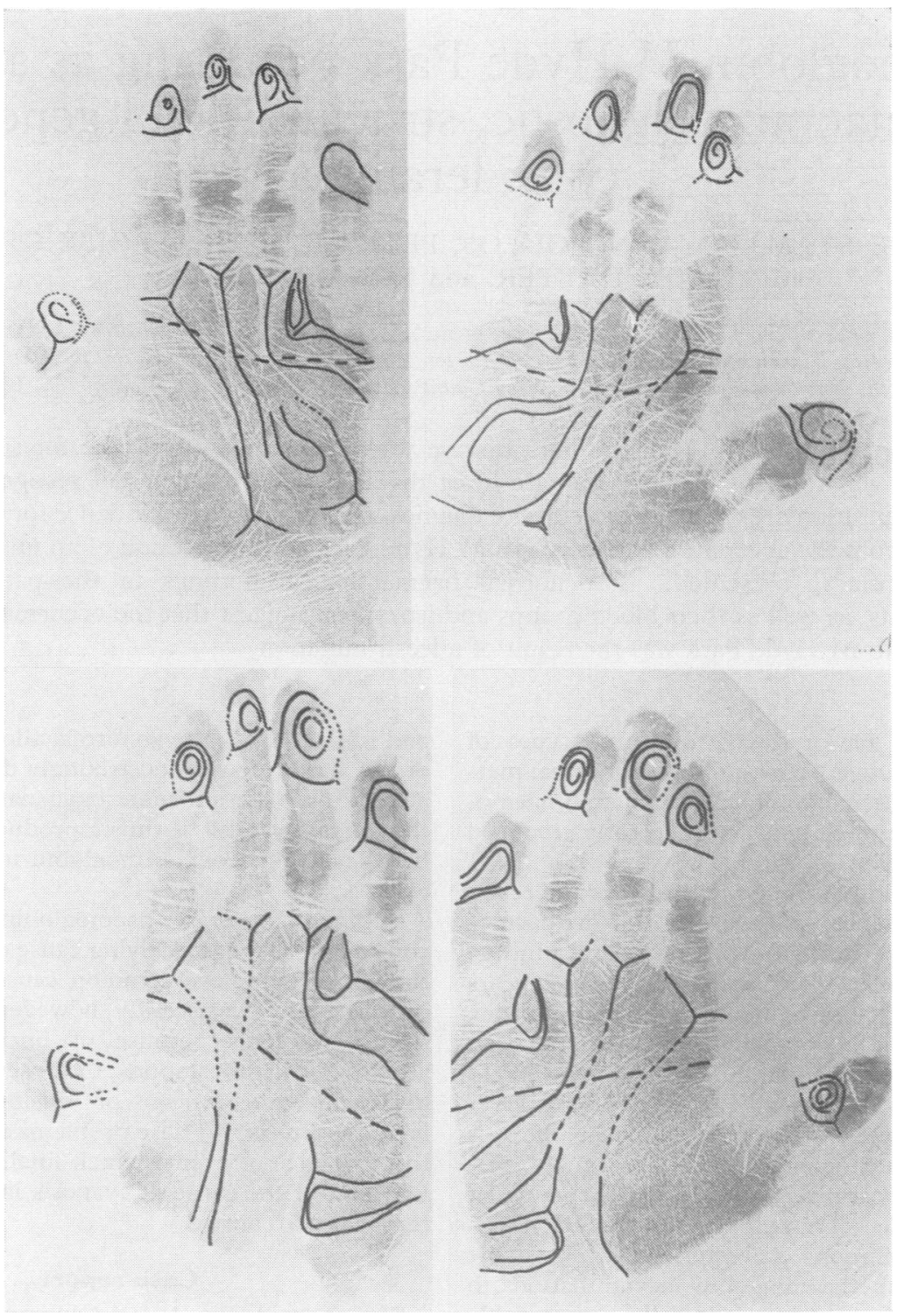

Fig. 5. The top dermatoglyphic prints are of the proband while the lower are of her affected sister. Four outstanding identical features are noted, the first three of which were also observed in our previous two cases. These features are (1) the numerous palmar creases obliterating the normal structure of the ridges and openings of the sweat pores; (2) the many digital whorls extending beyond the first interphalangeal creases; (3) the strikingly abnormal vertical orientation of the radiants; and (4) the presence of simian creases (the horizontal dashed lines). 